\title{
EVALUASI KINERJA ANGKUTAN UMUM PENUMPANG KOTA MATARAM (STUDI KASUS : RUTE SWETA - AMPENAN)
}

\section{Performance Evaluation of Public Passenger Transport In The City of Mataram (Case Study : Route Sweta - Ampenan)}

\author{
Hilda Yuliana ${ }^{1}$ \& Khoirul Abadi²
}

\author{
1,2 Jurusan Teknik Sipil Univ.Muhammadiyah Malang \\ Alamat Korespondensi : Jl. Tlogomas No 246 Telp (0341)464318-319 pes.130 \\ Email : ${ }^{1)}$ hildaunny@gmail.com
}

\begin{abstract}
The Passangers Public transport that was operation in the city of Mataram commonly called bemo is one of the means of transport that often used by peoples to condduct their daily activities, but passangers public transport in the city of Mataram for now increasingly not interested. Until now there are 165 unit fleet of public transport passangers that still operation while the capacity of passangers public transport is 12 pass/vehicle. The purpose of this study is to know the performance of passangers public transport Sweta-Ampenan route. The method used is the empirical that used data from static survey and dynamic survey. The result of the performance study of passangers public transport Sweta - Ampenan route obtained a load factor average is $50,74 \%$, frequency average is $28 \mathrm{kend} / \mathrm{hour}$, average time headway is 2,12 minute, and the average of travel speed is $23,93 \mathrm{~km} / \mathrm{hour}$.
\end{abstract}

Keywords: Performance, Passangers Public Transport, Mataram city

\begin{abstract}
Abstrak
Angkutan Umum Penumpang yang beroperasi di Kota Mataram biasa disebut bemo adalah salah satu sarana transportasi yang sering digunakan masyarakat untuk melakukan aktifitas seharihari, namun angkutan umum penumpang tersebut saat ini semakin tidak diminati masyarakat. Armada angkutan umum penumpang yang masih beroperasi sampai saat ini sebesar 165 unit dengan kapasitas angkutan umum penumpang sebesar 12 pnp/kend. Tujuan dari studi ini adalah untuk mengetahui kinerja angkutan umum penumpang rute Sweta - Ampenan. Metode yang digunakan dalam studi ini yaitu metode empiris dengan menggunakan data hasil survey statis dan survey dinamis. Hasil studi kinerja angkutan umum penumpang rute Sweta - Ampenan diperoleh nilai load factor rata - rata sebesar 50,74\%, frekuensi rata-rata sebesar $28 \mathrm{kend} / \mathrm{jam}$, headway waktu rata - rata sebesar 2,12 menit, dan kecepatan tempuh rata - rata sebesar $23,93 \mathrm{~km} / \mathrm{jam}$.
\end{abstract}

Kata Kunci : Kinerja, Angkutan Umum Penumpang, Kota Mataram

\section{PENDAHULUAN}

Angkutan Umum Penumpang di Kota Mataram biasa disebut bemo adalah salah satu sarana transportasi yang digunakan untuk melayani aktifitas masyarakat di Kota Mataram. Berdasarkan keputusan Walikota Mataram No : 14/KPTS/2000 tentang penetapan lintasan trayek angkutan umum penumpang dalam jaringan trayek Kota Mataram, terdapat 13 jaringan trayek untuk pelayanan penumpang, yang terdiri dari 2 trayek utama dengan jumlah armada 388 unit, 3 trayek cabang 10 unit, dan 8 trayek ranting 39 unit. Dari 13 jaringan trayek tersebut yang masih beroperasi sampai saat ini hanya angkutan umum penumpang rute Sweta - Ampenan. Berdasarkan Peraturan Walikota Mataram No : 17 Tahun 2013 tarif angkutan umum penumpang jauh dekat adalah Rp. 4000 untuk penumpang umum dan Rp. 3000 untuk penumpang pelajar berseragam.

Angkutan umum penumpang rute Sweta Ampenan adalah angkutan umum penumpang yang beroperasi melayani penumpang dari terminal Mandalika ke Kebon Roek maupun sebaliknya. Panjang rute pergi angkutan umum penumpang dari Sweta - Ampenan yaitu 22,6 km dan rute kembali angkutan umum penumpang dari Ampenan (Kebon 
Roek) - Sweta yaitu 20,6 km. Jumlah total armada angkutan umum penumpang rute Sweta - Ampenan adalah 199 unit, sedangkan yang masih beroperasi sampai saat ini adalah 165 unit. Operasional angkutan umum penumpang rata - rata 2 kali pulang pergi atau 4 rit perjalanan setiap harinya. Angkutan umum penumpang rute Sweta - Ampenan beroperasi mulai pukul 05.00 WITA sampai pukul 18.00 WITA dengan kapasitas 12 pnp/kend. Waktu tempuh angkutan umum penumpang dari arah Sweta (Mandalika) - Ampenan (Kebon Roek)sekitar 1,5 jam. Penyimpangan operasional seperti rute dan tarif yang dilakukan oleh beberapa oknum sopir angkutan umum penumpang rute Sweta - Ampenan. Penyimpangan tarif angkutan umum penumpang rute Sweta - Ampenan yang semula Rp. 4000 menjadi Rp. 5000. Penyimpangan rute masih dilakukan oknum sopir angkutan umum penumpang di waktu - waktu tertentu, hal tersebut terjadi karena kurangnya penumpang pada rute rencana.

Tujuan studi ini untuk mengetahui kinerja angkutan umum penumpang rute Sweta - Ampenan kondisi saat sekarang (2014). Adapun manfaat dari studi ini adalah sebagai bahan pertimbangan dan masukan bagi instansi terkait Kota Mataram untuk memperbaiki pelayanan angkutan umum penumpang.

\section{Angkutan Umum Penumpang}

Angkutan umum penumpang adalah angkutan penumpang yang dilakukan dengan sistem bayar atau sewa. Termasuk dalam pengertian angkutan umum penumpang adalah angkutan kota (bus, minibus, mikrolet dsb), kereta api, angkutan air dan angkutan udara. (Warpani, 1990:170)

Menurut Warpani (1990:171), pengadaan pelayanan AUP memang secara langsung mengurangi banyaknya kendaraan pribadi, namun AUP bukan salah satu jalan keluar untuk menyelesaikan masalah lalu-lintas kota. Pelayanan AUP akan berjalan dengan baik apabila tercipta keseimbangan antara penyediaan dan permintaan. Dalam hal ini partisipasi pemerintah sangat diperlukan dengan tujuan:(a)Menjamin sistem operasi yang sama bagi kepentingan masyarakat pengguna jasa angkutan, petugas pengelola angkutan dan pengusaha jasa angkutan. (b)Mengarahkan agar lingkungan tidak terlalu terganggu kegiatan
angkutan.(c)Menciptakan persaingan sehat dan menghindarkan kembaran yang tidak perlu.(d)Membantu perkembangan dan pembangunan nasional maupun daerah dengan meningkatkan pelayanan jasa angkutan. (e)Menjamin pemerataan jasa angkutan sehingga tidak ada pihak yang dirugikan.(f) Mengendalikan operasi pelayanan jasa angkutan.

Indikator kualitas pelayanan operasi angkutan dapat dilihat dari nilai kinerja operasi yang dihasilkan, parameter yang digunakan frekuensi, headway, load factor, kecepatan perjalanan.Asikin (2001,hal 22).

Frekuensi adalah jumlah kendaraan yang lewat per satuan waktu Morlok (1978). Frekuensi dapat dirumuskan sebagai berikut :

$\mathbf{F}=\mathbf{1} / \mathbf{h}$ Pers. 1

Dimana :

$\mathrm{F}=$ frekuensi

$\mathrm{h}=$ headway (menit)

Headway adalah waktu antara satu kendaraan dengan kendaraan lain yang berurutan dibelakangny pada satu rute yang sama Asikin (2001). Headway yang ideal adalah 5-10 menit, headway puncak adalah 2 - 5 menit (Direktorat Jendral Perhubungan Darat, 1996), Nilai headway dirumuskan sebagai berikut :

$\mathbf{H t}=\frac{60}{Q / j a m} \quad$ Pers. 2

Dimana

$$
\begin{aligned}
& Q / \text { jam }=\text { jumlah kendaraan dalam satu jam } \\
& \mathrm{Ht} \quad=\text { headway }(\text { menit })
\end{aligned}
$$

Load factor (LF) merupakan perbandingan antara kapasitas terjual dan kapasitas tersedia untuk satu perjalanan yang biasa dinyatakan dalam persen (\%) (Abubakar,1995).

$$
\mathbf{L F}=\frac{I F}{C} \boldsymbol{x} \mathbf{1 0 0} \% \quad \text { Pers. } 3
$$

Dimana :

$$
\begin{aligned}
& \mathrm{LF}=\text { Load Factor }(\%) \\
& \mathrm{JF}=\text { Banyaknya penumpang yang diangkut } \\
& \text { sepanjang satu lintasan sekali jalan. }
\end{aligned}
$$




$$
\text { C = kapasitas kendaraan. }
$$

Menurut Direktorat Jendral Perhubungan Darat (1995), bahwa nilai load factor dalam kondisi dinamis $70 \%$.

Menurut Morlok (1978) menyatakan bahwa kecepatan perjalanan yaitu kecepatan kendaraan dari awal rute ke titik akhir rute, dan dirumuskan dengan :

$\mathbf{V}=\mathbf{S} / \mathbf{t}$ Pers. 4

Dimana :
$\mathrm{V}=$ Kecepatan tempuh angkutan umum $(\mathrm{Km} / \mathrm{jam})$

$\mathrm{S}$ = Jarak Tempuh Angkutan Umum (Km)

$\mathrm{t} \quad=$ Waktu Tempuh Angkutan Umum (Jam)

\section{METODE PENELITIAN}

\section{Wilayah Studi dan Zona}

Angkutan umum penumpang pada rute Sweta - Ampenan Kota Mataram dengan rute regular terminal Mandalika - Kebon Roek. Panjang rute arah Sweta - Ampenan $\pm 22,6 \mathrm{~km}$ dan panjang rute arah Ampenan - Sweta $\pm 20,6 \mathrm{~km}$

Tabel 1. Pembagian Zona AUP Rute Sweta - Ampenan.

\begin{tabular}{clcl}
\hline Zona & \multicolumn{1}{c}{ Sweta - Ampenan } & Zona & \multicolumn{1}{c}{ Ampenan - Sweta } \\
\hline 1 & Terminal Mandalika - Plaza MGM & 8 & Kebon Roek - Simpang Ampenan \\
2 & Plaza MGM - Pasar Bali & 9 & Simpang Ampenan - RS Tentara \\
3 & Pasar Bali - RS Siti Hajar & 10 & RS Tentara - Islamic Centre \\
4 & RS Siti Hajar - Universitas Mataram & 11 & Islamic Centre - SMK Kusuma \\
5 & Universitas Mataram - Lapangan Malomba & 12 & SMK Kusuma - Bank NTB \\
6 & Lapangan Malomba - SMPN 14 Mataram & 13 & Bank NTB - Masjid Nurul Yaqin \\
7 & SMPN 14 Mataram - Kebon Roek & \multirow{2}{*}{14} & Masjid Nurul Yaqin - Terminal \\
\hline
\end{tabular}

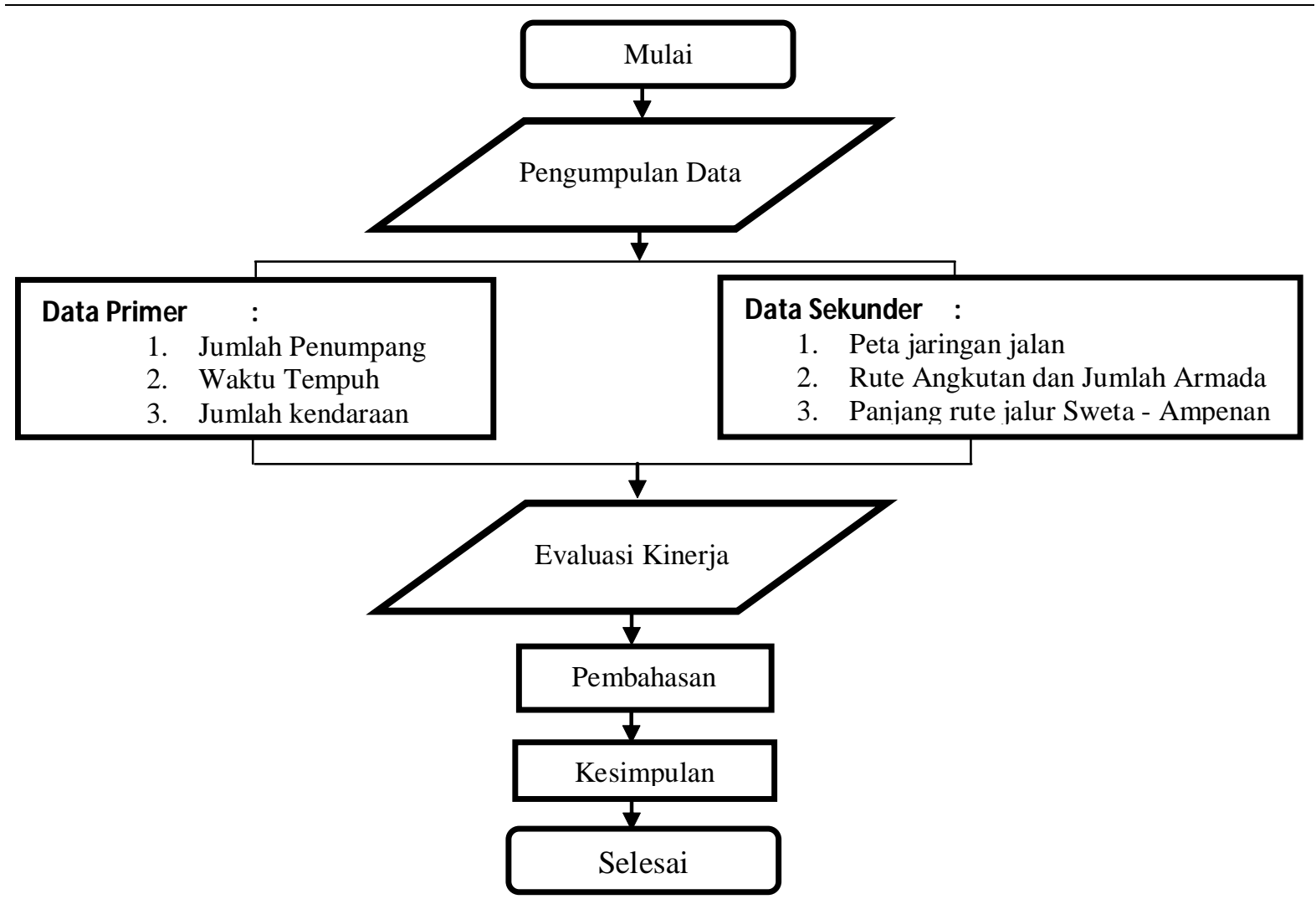

Gambar 1. Bagan Alir Tahapan Studi

HASIL DAN PEMBAHASAN

Data Penumpang dan Waktu Tempuh
Hasil survey yang dilakukan mulai pukul 06.00 WITA sampai pukul 18.00 WITA untuk mendapatkan data penumpang dan waktu tempuh disajikan pada tabel 2 dan 3 serta data penumpang 
naik turun sepanjang perjalan pada masing-masing angkutan umum penumpang disajikan pada tabel 4 .

Tabel 2. Data Penumpang dan Waktu Tempuh AUP Sweta - Ampenan arah Sweta - Ampenan. ]

\begin{tabular}{|c|c|c|c|c|c|c|c|c|c|c|c|c|c|c|c|c|c|c|}
\hline \multirow{3}{*}{$\begin{array}{c}\text { Jam } \\
\text { Berangkat }\end{array}$} & \multicolumn{3}{|c|}{ Sabtu } & \multicolumn{3}{|c|}{ Minggu } & \multicolumn{3}{|c|}{ Senin } & \multicolumn{3}{|c|}{ Selasa } & \multicolumn{3}{|c|}{ Rabu } & \multicolumn{3}{|c|}{ Kamis } \\
\hline & $\mathrm{Pr}$ & & Waktu & $\mathrm{Pn}$ & & Waktu & Pn & & Waktu & $\mathrm{Pn}_{1}$ & & Waktu & $\mathrm{Pl}$ & & Waktu & & & Waktu \\
\hline & $\mathrm{U}$ & $\mathrm{P}$ & $\begin{array}{l}\text { Tempuh } \\
\text { (Menit) }\end{array}$ & $\mathrm{U}$ & $\mathrm{P}$ & $\begin{array}{l}\text { Tempuh } \\
\text { (Menit) }\end{array}$ & $\mathrm{U}$ & $\mathrm{P}$ & $\begin{array}{l}\text { Tempuh } \\
\text { (Menit) }\end{array}$ & $\mathrm{U}$ & $\mathrm{P}$ & $\begin{array}{l}\text { Tempuh } \\
\text { (Menit) }\end{array}$ & $\mathrm{U}$ & $\mathrm{P}$ & $\begin{array}{l}\text { Tempuh } \\
\text { (Menit) }\end{array}$ & $\mathrm{U}$ & $\mathrm{P}$ & $\begin{array}{l}\text { Tempuh } \\
\text { (Menit) }\end{array}$ \\
\hline 06.00 & 5 & 0 & 52 & 3 & 0 & 50 & 3 & 0 & 50 & 4 & 0 & 56 & 3 & 0 & 54 & 5 & 0 & 48 \\
\hline 06.30 & 6 & 0 & 54 & 5 & 0 & 46 & 5 & 0 & 50 & 6 & 0 & 48 & 7 & 0 & 58 & 5 & 0 & 50 \\
\hline 07.00 & 8 & 0 & 50 & 3 & 0 & 54 & 6 & 0 & 52 & 8 & 0 & 55 & 5 & 0 & 48 & 7 & 0 & 59 \\
\hline 08.00 & 5 & 0 & 56 & 6 & 0 & 48 & 4 & 0 & 54 & 5 & 0 & 50 & 5 & 0 & 51 & 8 & 0 & 54 \\
\hline 08.30 & 6 & 0 & 58 & 4 & 0 & 51 & 6 & 0 & 45 & 5 & 0 & 48 & 8 & 0 & 50 & 10 & 0 & 58 \\
\hline 10.00 & 9 & 0 & 61 & 10 & 0 & 56 & 8 & 0 & 59 & 8 & 0 & 65 & 9 & 0 & 59 & 10 & 0 & 58 \\
\hline 11.00 & 9 & 0 & 56 & 9 & 0 & 61 & 11 & 0 & 51 & 10 & 0 & 59 & 11 & 0 & 49 & 11 & 0 & 60 \\
\hline 12.00 & 8 & 0 & 51 & 5 & 0 & 58 & 5 & 0 & 54 & 10 & 0 & 59 & 7 & 0 & 51 & 7 & 0 & 56 \\
\hline 12.30 & 5 & 0 & 42 & 4 & 0 & 48 & 4 & 0 & 45 & 5 & 0 & 50 & 5 & 0 & 58 & 4 & 0 & 47 \\
\hline 13.00 & 7 & 0 & 48 & 5 & 0 & 59 & 4 & 0 & 57 & 5 & 0 & 56 & 4 & 0 & 40 & 6 & 0 & 59 \\
\hline 13.30 & 4 & 0 & 46 & 9 & 0 & 50 & 9 & 0 & 48 & 4 & 0 & 47 & 4 & 0 & 50 & 5 & 0 & 45 \\
\hline 14.00 & 6 & 2 & 56 & 6 & 0 & 55 & 4 & 0 & 56 & 4 & 2 & 58 & 3 & 2 & 56 & 7 & 2 & 54 \\
\hline 15.00 & 8 & 0 & 48 & 10 & 0 & 49 & 5 & 3 & 55 & 5 & 4 & 50 & 4 & 3 & 59 & 6 & 3 & 56 \\
\hline 16.00 & 8 & 0 & 58 & 10 & 0 & 57 & 7 & 2 & 56 & 7 & 0 & 49 & 10 & 0 & 50 & 10 & 0 & 50 \\
\hline 17.00 & 8 & 0 & 62 & 9 & 0 & 58 & 10 & 0 & 65 & 9 & 0 & 61 & 8 & 0 & 59 & 10 & 0 & 62 \\
\hline 18.00 & 9 & 0 & 61 & 8 & 0 & 54 & 8 & 0 & 55 & 10 & 0 & 59 & 10 & 0 & 57 & 8 & 0 & 56 \\
\hline
\end{tabular}

Sumber : Hasil Survey

Keterangan : $\mathrm{U}=$ Umum $\mathrm{P}=$ Pelajar

Tabel 3. Data Penumpang dan Waktu Tempuh AUP Sweta - Ampenan arah Ampenan - Sweta

\begin{tabular}{|c|c|c|c|c|c|c|c|c|c|c|c|c|c|c|c|c|c|c|}
\hline \multirow{3}{*}{$\begin{array}{c}\text { Jam } \\
\text { Berangkat }\end{array}$} & \multicolumn{3}{|c|}{ Sabtu } & \multicolumn{3}{|c|}{ Minggu } & \multicolumn{3}{|c|}{ Senin } & \multicolumn{3}{|c|}{ Selasa } & \multicolumn{3}{|c|}{ Rabu } & \multicolumn{3}{|c|}{ Kamis } \\
\hline & \multicolumn{2}{|c|}{ Pnp } & \multirow{2}{*}{$\begin{array}{l}\text { Waktu } \\
\text { Tempuh } \\
\text { (Menit) }\end{array}$} & \multicolumn{2}{|c|}{ Pnp } & \multirow{2}{*}{$\begin{array}{l}\text { Waktu } \\
\text { Tempuh } \\
\text { (Menit) }\end{array}$} & \multicolumn{2}{|c|}{ Pnp } & \multirow{2}{*}{$\begin{array}{l}\text { Waktu } \\
\text { Tempuh } \\
\text { (Menit) }\end{array}$} & \multicolumn{2}{|c|}{ Pnp } & \multirow{2}{*}{$\begin{array}{l}\text { Waktu } \\
\text { Tempuh } \\
\text { (menit) }\end{array}$} & \multicolumn{2}{|c|}{ Pnp } & \multirow{2}{*}{$\begin{array}{l}\text { Waktu } \\
\text { Tempuh } \\
\text { (menit) }\end{array}$} & \multicolumn{2}{|c|}{ Pnp } & \multirow{2}{*}{$\begin{array}{l}\text { Waktu } \\
\text { Tempuh } \\
\text { (menit) }\end{array}$} \\
\hline & $\mathrm{U}$ & $\mathrm{P}$ & & $\mathrm{U}$ & $\mathrm{P}$ & & $\mathrm{U}$ & $\mathrm{P}$ & & $\mathrm{U}$ & $\mathrm{P}$ & & $\mathrm{U}$ & $\mathrm{P}$ & & $\mathrm{U}$ & $\mathrm{P}$ & \\
\hline 06.00 & 2 & 0 & 48 & 3 & 0 & 50 & 3 & 0 & 49 & 4 & 0 & 50 & 4 & 0 & 48 & 3 & 0 & 49 \\
\hline 06.30 & 2 & 0 & 50 & 2 & 0 & 45 & 2 & 0 & 51 & 4 & 0 & 56 & 3 & 0 & 53 & 4 & 0 & 51 \\
\hline 07.00 & 3 & 0 & 52 & 5 & 0 & 54 & 4 & 0 & 52 & 6 & 0 & 54 & 4 & 0 & 50 & 6 & 0 & 53 \\
\hline 08.00 & 4 & 0 & 54 & 6 & 0 & 58 & 5 & 0 & 56 & 6 & 0 & 55 & 5 & 0 & 54 & 5 & 0 & 52 \\
\hline 08.30 & 4 & 0 & 53 & 5 & 0 & 51 & 3 & 0 & 54 & 3 & 0 & 55 & 4 & 0 & 52 & 5 & 0 & 57 \\
\hline 10.00 & 2 & 0 & 52 & 3 & 0 & 54 & 4 & 0 & 51 & 5 & 0 & 54 & 5 & 0 & 57 & 6 & 0 & 54 \\
\hline 11.00 & 4 & 0 & 50 & 7 & 0 & 59 & 6 & 0 & 55 & 4 & 0 & 58 & 6 & 0 & 56 & 4 & 0 & 58 \\
\hline 12.00 & 6 & 0 & 56 & 5 & 0 & 52 & 3 & 0 & 52 & 5 & 0 & 51 & 6 & 0 & 58 & 6 & 0 & 59 \\
\hline 12.30 & 5 & 0 & 51 & 5 & 0 & 52 & 5 & 0 & 57 & 6 & 0 & 56 & 6 & 0 & 55 & 5 & 0 & 51 \\
\hline 13.00 & 3 & 3 & 59 & 6 & 0 & 56 & 5 & 0 & 50 & 4 & 0 & 57 & 4 & 0 & 59 & 9 & 0 & 59 \\
\hline 13.30 & 7 & 2 & 62 & 6 & 0 & 56 & 2 & 3 & 61 & 5 & 4 & 63 & 2 & 4 & 62 & 4 & 3 & 61 \\
\hline 14.00 & 3 & 0 & 52 & 5 & 0 & 54 & 5 & 2 & 56 & 4 & 3 & 61 & 5 & 2 & 58 & 7 & 2 & 62 \\
\hline 15.00 & 6 & 0 & 53 & 9 & 0 & 62 & 4 & 0 & 58 & 7 & 0 & 58 & 6 & 0 & 58 & 6 & 0 & 58 \\
\hline 16.00 & 8 & 0 & 62 & 8 & 0 & 54 & 6 & 0 & 59 & 7 & 0 & 58 & 7 & 0 & 61 & 8 & 0 & 63 \\
\hline 17.00 & 5 & 0 & 59 & 8 & 0 & 58 & 6 & 0 & 58 & 6 & 0 & 59 & 8 & 0 & 62 & 7 & 0 & 62 \\
\hline 18.00 & 4 & 0 & 63 & 8 & 0 & 56 & 6 & 0 & 61 & 7 & 0 & 62 & 7 & 0 & 59 & 6 & 0 & 61 \\
\hline
\end{tabular}

Sumber : Hasil Survey

Keterangan : $\mathrm{U}=$ Umum $\mathrm{P}=$ Pelajar

Tabel 4. Pola Naik Turun Penumpang AUP Rute Sweta - Ampenan Hari Kamis, 14 Agustus 2014

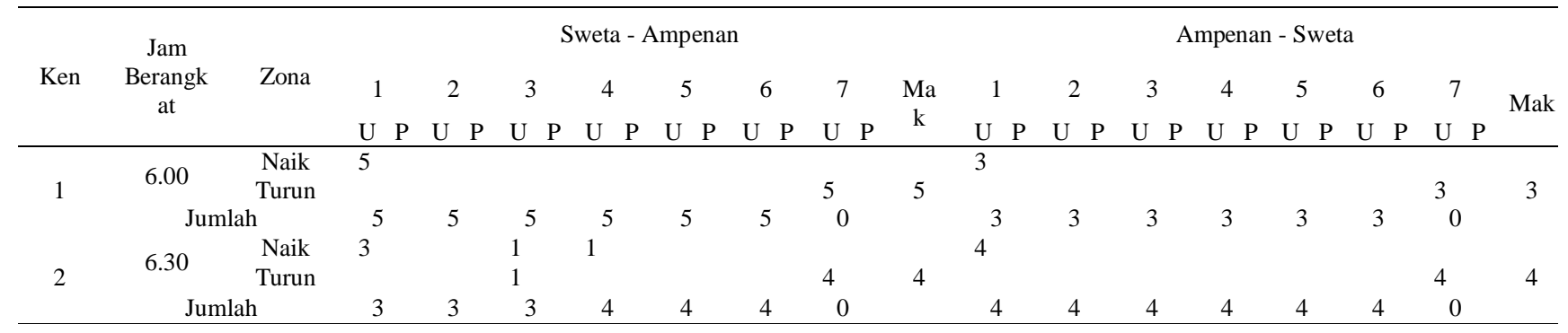




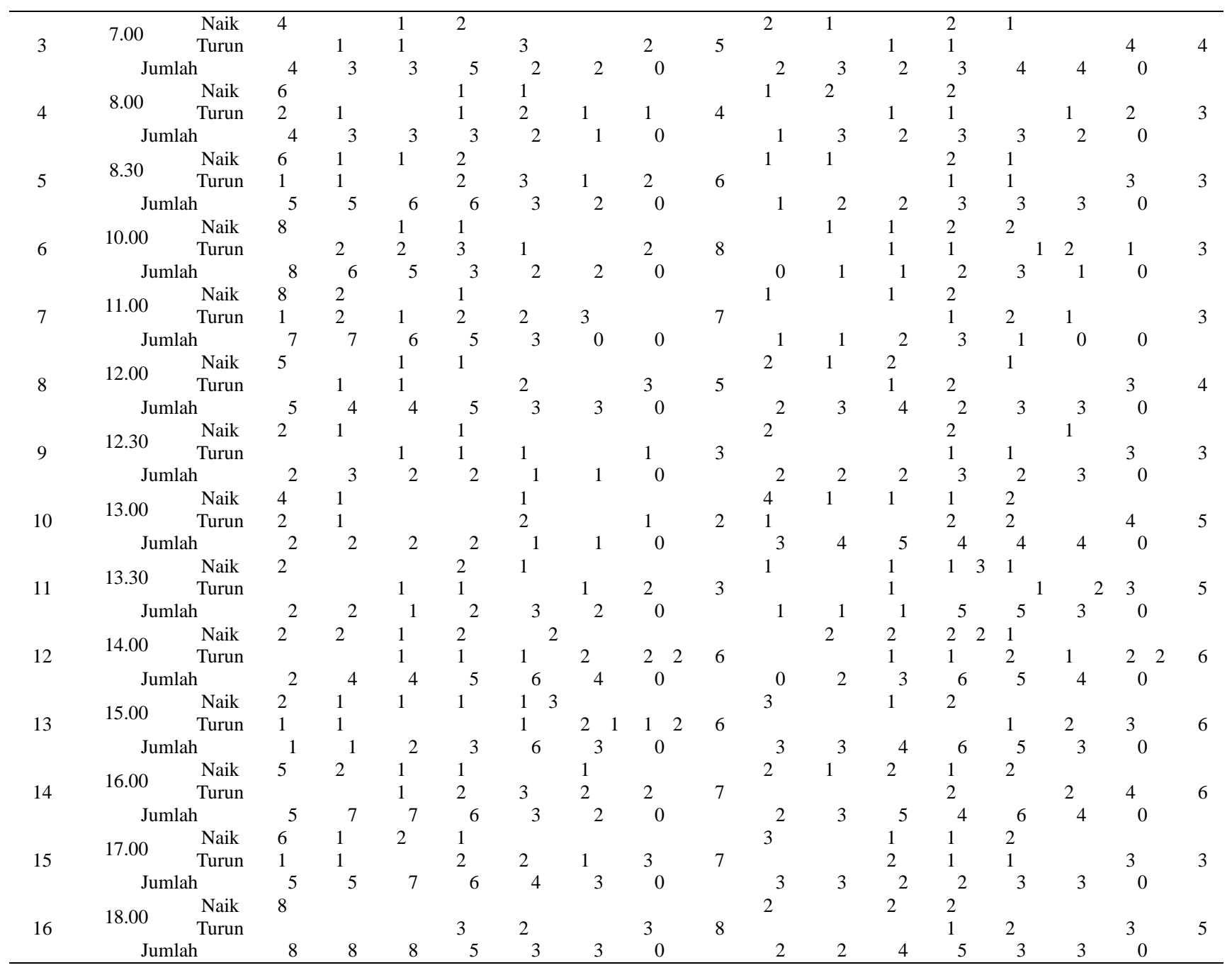

\section{Jumlah Kendaraan}

Jumlah armada angkutan umum penumpang rute Sweta - Ampenan yang beroperasi sebesar 165 unit dengan jumlah kendaraan angkutan umum penumpang rute Sweta - Ampenan yang melewati lokasi pengamatan disajikan pada tabel 5 .

Tabel 5. Jumlah Kendaraan AUP Rute Sweta - Ampenan (Kendaraan / 15 Menit)

\begin{tabular}{|c|c|c|c|c|c|c|c|c|c|c|c|c|}
\hline \multicolumn{7}{|c|}{ Sweta - Ampenan } & \multicolumn{6}{|c|}{ Ampenan - Sweta } \\
\hline \multirow{3}{*}{ Jam } & Sabtu & Minggu & Senin & Selasa & Rabu & Kamis & Sabtu & Minggu & Senin & Selasa & Rabu & Kamis \\
\hline & Jumlah & Jumlah & Jumlah & Jumlah & Jumlah & Jumlah & Jumlah & Jumlah & Jumlah & Jumlah & Jumlah & Jumlah \\
\hline & Kend. & Kend. & Kend. & Kend. & Kend. & Kend. & Kend. & Kend. & Kend. & Kend. & Kend. & Kend. \\
\hline $06.00-06.15$ & 6 & 8 & 8 & 5 & 5 & 7 & 5 & 5 & 7 & 6 & 7 & 5 \\
\hline $06.15-06.30$ & 6 & 8 & 7 & 7 & 6 & 5 & 5 & 6 & 6 & 6 & 7 & 7 \\
\hline $06.30-06.45$ & 5 & 6 & 7 & 7 & 6 & 7 & 6 & 5 & 6 & 5 & 9 & 7 \\
\hline 06.45-07.00 & 7 & 5 & 8 & 9 & 5 & 7 & 6 & 7 & 7 & 6 & 9 & 6 \\
\hline $07.00-07.15$ & 9 & 7 & 7 & 8 & 8 & 9 & 7 & 6 & 7 & 6 & 8 & 7 \\
\hline $07.15-07.30$ & 9 & 6 & 7 & 8 & 8 & 8 & 7 & 8 & 7 & 7 & 9 & 7 \\
\hline $07.30-07.45$ & 9 & 6 & 6 & 8 & 9 & 6 & 9 & 7 & 9 & 7 & 9 & 7 \\
\hline $07.45-08.00$ & 8 & 6 & 8 & 9 & 8 & 8 & 9 & 7 & 9 & 9 & 9 & 9 \\
\hline $08.00-08.15$ & 9 & 8 & 8 & 7 & 8 & 8 & 6 & 8 & 8 & 8 & 7 & 8 \\
\hline $08.15-08.30$ & 8 & 8 & 7 & 7 & 8 & 8 & 7 & 7 & 9 & 9 & 8 & 8 \\
\hline $08.30-08.45$ & 8 & 9 & 7 & 9 & 8 & 7 & 7 & 6 & 8 & 8 & 7 & 8 \\
\hline 08.45-09.00 & 7 & 9 & 7 & 7 & 7 & 8 & 7 & 6 & 7 & 8 & 7 & 7 \\
\hline $09.00-09.15$ & 7 & 8 & 5 & 6 & 8 & 7 & 9 & 7 & 6 & 7 & 7 & 9 \\
\hline $09.15-09.30$ & 6 & 7 & 6 & 6 & 7 & 8 & 8 & 9 & 6 & 6 & 6 & 8 \\
\hline $09.30-09.45$ & 6 & 7 & 7 & 8 & 7 & 8 & 7 & 9 & 9 & 7 & 7 & 6 \\
\hline $09.45-10.00$ & 6 & 6 & 7 & 8 & 9 & 8 & 9 & 8 & 8 & 7 & 6 & 6 \\
\hline
\end{tabular}




\begin{tabular}{|c|c|c|c|c|c|c|c|c|c|c|c|c|}
\hline $10.00-10.15$ & 7 & 7 & 8 & 9 & 9 & 7 & 9 & 9 & 9 & 7 & 8 & 6 \\
\hline $10.15-10.30$ & 7 & 7 & 9 & 6 & 7 & 9 & 8 & 7 & 9 & 7 & 8 & 8 \\
\hline $10.30-10.45$ & 7 & 7 & 9 & 7 & 7 & 7 & 8 & 6 & 7 & 6 & 9 & 8 \\
\hline $10.45-11.00$ & 7 & 8 & 8 & 7 & 9 & 7 & 6 & 8 & 6 & 6 & 8 & 8 \\
\hline $11.00-11.15$ & 8 & 8 & 8 & 6 & 9 & 9 & 9 & 7 & 8 & 8 & 9 & 7 \\
\hline $11.15-11.30$ & 7 & 8 & 9 & 8 & 8 & 9 & 9 & 7 & 9 & 8 & 7 & 9 \\
\hline $11.30-11.45$ & 8 & 9 & 6 & 8 & 6 & 8 & 8 & 9 & 9 & 6 & 7 & 7 \\
\hline $11.45-12.00$ & 6 & 8 & 7 & 8 & 7 & 8 & 8 & 7 & 8 & 6 & 7 & 8 \\
\hline $12.00-12.15$ & 8 & 8 & 8 & 9 & 6 & 7 & 8 & 7 & 9 & 8 & 8 & 7 \\
\hline $12.15-12.30$ & 6 & 8 & 7 & 6 & 7 & 7 & 6 & 8 & 9 & 8 & 8 & 7 \\
\hline $12.30-12.45$ & 7 & 9 & 8 & 8 & 7 & 7 & 7 & 7 & 7 & 9 & 7 & 9 \\
\hline $12.45-13.00$ & 6 & 9 & 8 & 9 & 7 & 9 & 8 & 7 & 6 & 9 & 7 & 8 \\
\hline $13.00-13.15$ & 9 & 6 & 6 & 8 & 9 & 7 & 8 & 9 & 7 & 8 & 7 & 9 \\
\hline $13.15-13.30$ & 9 & 7 & 7 & 8 & 9 & 6 & 7 & 9 & 7 & 9 & 9 & 9 \\
\hline $13.30-13.45$ & 9 & 7 & 7 & 8 & 8 & 6 & 6 & 9 & 7 & 9 & 9 & 7 \\
\hline $13.45-14.00$ & 7 & 7 & 9 & 8 & 9 & 9 & 7 & 8 & 7 & 7 & 9 & 8 \\
\hline $14.00-14.15$ & 7 & 7 & 9 & 9 & 8 & 8 & 7 & 7 & 7 & 7 & 9 & 8 \\
\hline $14.15-14.30$ & 9 & 7 & 9 & 7 & 9 & 8 & 8 & 7 & 8 & 7 & 9 & 8 \\
\hline $14.30-14.45$ & 7 & 8 & 9 & 6 & 8 & 7 & 8 & 7 & 8 & 8 & 7 & 9 \\
\hline $14.45-15.00$ & 6 & 9 & 6 & 8 & 8 & 7 & 6 & 6 & 7 & 9 & 8 & 8 \\
\hline $15.00-15.15$ & 6 & 9 & 6 & 7 & 9 & 9 & 6 & 8 & 9 & 9 & 9 & 8 \\
\hline $15.15-15.30$ & 9 & 7 & 8 & 9 & 9 & 8 & 5 & 8 & 7 & 6 & 9 & 8 \\
\hline $15.30-15.45$ & 8 & 8 & 7 & 8 & 7 & 9 & 7 & 5 & 6 & 6 & 6 & 7 \\
\hline $15.45-16.00$ & 9 & 6 & 7 & 8 & 7 & 8 & 8 & 7 & 6 & 5 & 6 & 7 \\
\hline $16.00-16.15$ & 9 & 8 & 8 & 9 & 7 & 6 & 8 & 7 & 5 & 7 & 6 & 6 \\
\hline $16.15-16.30$ & 7 & 7 & 6 & 7 & 8 & 6 & 9 & 7 & 6 & 7 & 9 & 6 \\
\hline $16.30-16.45$ & 7 & 7 & 6 & 7 & 6 & 7 & 7 & 6 & 5 & 8 & 7 & 5 \\
\hline $16.45-17.00$ & 5 & 6 & 7 & 5 & 6 & 7 & 7 & 8 & 5 & 7 & 8 & 7 \\
\hline $17.00-17.15$ & 6 & 6 & 6 & 5 & 7 & 5 & 5 & 8 & 7 & 7 & 6 & 6 \\
\hline $17.15-17.30$ & 6 & 5 & 5 & 6 & 7 & 7 & 5 & 6 & 5 & 6 & 6 & 7 \\
\hline $17.30-17.45$ & 6 & 5 & 5 & 6 & 7 & 5 & 6 & 6 & 7 & 6 & 5 & 7 \\
\hline $17.45-18.00$ & 6 & 5 & 5 & 6 & 7 & 5 & 6 & 7 & 7 & 6 & 5 & 7 \\
\hline
\end{tabular}

Catatan : Tempat pencatatan AUP arah Sweta - Ampenan pada Jl. Catur Warga Tempat Pencatatan AUP arah Ampenan - Sweta pada Jl. Pejanggik

Sumber : Hasil Survey

Kinerja Angkutan Umum Penumpang

Load Factor (Faktor muat)
Load factor angkutan umum penumpang dihitung berdasarkan data penumpang (tabel 2 dan 3) dengan kapasitas angkutan 12 pnp/kend disajikan pada tabel 6 .

Tabel 6. Load Factor AUP Jalur Sweta - Ampenan (\%)

\begin{tabular}{|c|c|c|c|c|c|c|c|c|c|c|c|c|}
\hline & \multicolumn{6}{|c|}{ Sweta-Ampenan } & \multicolumn{6}{|c|}{ Ampenan - Sweta } \\
\hline & Sabtu & Minggu & Senin & $\begin{array}{c}\text { Selas } \\
\text { a }\end{array}$ & Rabu & Kamis & $\begin{array}{c}\text { Sabt } \\
\mathrm{u}\end{array}$ & Minggu & Senin & Selasa & Rabu & Kamis \\
\hline Maksimum & 75,00 & 83,33 & 91,67 & 83,33 & $\begin{array}{c}91,6 \\
7\end{array}$ & 91,67 & 75,00 & 75,00 & 58,33 & 75,00 & 58,33 & 75,00 \\
\hline Minimum & 33,33 & 25,00 & 25,00 & 33,33 & $\begin{array}{c}25,0 \\
0\end{array}$ & 33,33 & 16,67 & 16,67 & 16,67 & 25,00 & 25,00 & 25,00 \\
\hline Rata-rata & 58,85 & 55,20 & 24,16 & 54,68 & $\begin{array}{c}56,2 \\
5\end{array}$ & 64,58 & 38,02 & 45,83 & 38,54 & 48,67 & 45,83 & 49,99 \\
\hline $\begin{array}{l}\text { Maksimum } \\
\text { Minimum } \\
\text { Rata-rata }\end{array}$ & & & $\begin{array}{l}91,6 \\
25,0 \\
57,2\end{array}$ & & & & & & $\begin{array}{l}75 \\
16 \\
44\end{array}$ & & & \\
\hline $\begin{array}{l}\text { Maksimum } \\
\text { Minimum } \\
\text { Rata-rata }\end{array}$ & & & & & & $\begin{array}{l}91, \\
16, \\
50\end{array}$ & & & & & & \\
\hline
\end{tabular}

Sumber : Hasil Perhitungan

Load factor tertinggi dari arah Sweta - hari Senin, Rabu dan Kamis sebesar 91,67\% Ampenan terjadi pada keberangkatan pukul 11.00 sedangkan Load factor terendah terjadi pada 
keberangkatan pukul 06.00 WITA hari Minggu, Senin dan Rabu sebesar 25,00 \%. Load factor tertinggi dari arah Ampenan - Sweta terjadi pada keberangkatan pukul 13.30, 14.00 dan 15.00 WITA hari Sabtu, Minggu, Selasa dan Kamis sebesar 75 $\%$ sedangkan Load factor terendah terjadi pada keberangkatan pukul 06.00 dan 06.30 WITA hari Sabtu, Minggu dan Senin sebesar 16,67 \%. Load factor rata - rata arah Sweta - Ampenan sebesar $57,29 \%$ sedangkan Load factor rata - rata arah Ampenan - Sweta sebesar 44,18 \%, adapun Load factor rata-rata kedua arah sebesar 50,74\%. Diartikan bahwa tingkat keterisian dari angkutan umum penumpang rute Sweta - Ampenan kurang dari standar yang telah ditetapkan Direktorat Jenderal Perhubungan Darat sebesar $70 \%$.

\section{Frekuensi dan Headway}

Frekuensi dan headway angkutan umum penumpang berdasarkan data jumlah kendaraan (tabel 5) disajikan pada tabel 7 dan 8.

Tabel 7. Frekuensi Rata - rata AUP Rute Sweta - Ampenan (Kend/Jam)

\begin{tabular}{|c|c|c|c|c|c|c|c|c|c|c|c|c|}
\hline & \multicolumn{6}{|c|}{ Sweta - Ampenan } & \multicolumn{6}{|c|}{ Ampenan - Sweta } \\
\hline & Sabtu & Minggu & Senin & Selasa & Rabu & Kamis & Sabtu & Minggu & Senin & Selasa & Rabu & Kamis \\
\hline Maksimum & 35 & 34 & 36 & 34 & 35 & 34 & 34 & 35 & 35 & 35 & 36 & 35 \\
\hline Minimum & 23 & 21 & 21 & 22 & 22 & 22 & 22 & 23 & 21 & 23 & 22 & 24 \\
\hline Rata-rata & 27 & 27 & 27 & 28 & 29 & 28 & 27 & 27 & 27 & 27 & 29 & 28 \\
\hline Maksimum & \multicolumn{6}{|c|}{36} & \multicolumn{6}{|c|}{36} \\
\hline Minimum & \multirow{2}{*}{\multicolumn{6}{|c|}{$\begin{array}{l}21 \\
28\end{array}$}} & \multicolumn{6}{|c|}{21} \\
\hline Rata-rata & & & & & & & & & & 8 & & \\
\hline Maksimum & \multirow{2}{*}{\multicolumn{12}{|c|}{36}} \\
\hline Minimum & \multirow{2}{*}{\multicolumn{12}{|c|}{$\begin{array}{l}21 \\
28\end{array}$}} \\
\hline Rata-rata & & & & & & & & & & & & \\
\hline
\end{tabular}

Sumber : Hasil Perhitungan

Tabel 8. Headway Rata - rata AUP Rute Sweta - Ampenan (Menit)

\begin{tabular}{|c|c|c|c|c|c|c|c|c|c|c|c|c|}
\hline & \multicolumn{6}{|c|}{ Sweta - Ampenan } & \multicolumn{6}{|c|}{ Ampenan - Sweta } \\
\hline & Sabtu & Minggu & Senin & Selasa & Rabu & Kamis & Sabtu & Minggu & Senin & Selasa & Rabu & Kamis \\
\hline Maksimum & 2,61 & 2,86 & 2,86 & 2,71 & 2,73 & 2,73 & 2,73 & 2,61 & 2,86 & 2,61 & 2,73 & 2,50 \\
\hline Minimum & 1,71 & 1,76 & 1,67 & 1,76 & 1,71 & 1,76 & 1,76 & 1,71 & 1,71 & 1,71 & 1,67 & 1,71 \\
\hline Rata-rata & 1,95 & 1,96 & 1,96 & 1,96 & 1,87 & 1,90 & 1,96 & 1,95 & 1,96 & 1,96 & 1,85 & 1,91 \\
\hline Maksimum & \multicolumn{6}{|c|}{2,86} & \multicolumn{6}{|c|}{2,86} \\
\hline Minimum & \multicolumn{6}{|c|}{1,67} & \multicolumn{6}{|c|}{1,67} \\
\hline Rata-rata & \multicolumn{6}{|c|}{2,14} & \multicolumn{6}{|c|}{2,11} \\
\hline Maksimum & \multicolumn{12}{|c|}{2,86} \\
\hline Minimum & \multicolumn{12}{|c|}{1,67} \\
\hline Rata-rata & \multicolumn{12}{|c|}{2,12} \\
\hline
\end{tabular}

Angkutan umum penumpang arah Sweta Ampenan diperoleh frekuensi tertinggi sebesar 36 kend/jam dengan nilai headway terendah sebesar 1,67 menit pada pukul 13.45 - 14.45 WITA hari Senin, frekuensi terendah sebesar $21 \mathrm{kend} / \mathrm{jam}$ dengan headway tertinggi sebesar 2,86 menit pada pukul 17.00 - 18.00 WITA hari Minggu dan Senin. Sedangkan angkutan umum arah Ampenan - Sweta, frekuensi tertinggi sebesar $36 \mathrm{kend} / \mathrm{jam}$ dengan headway terendah sebesar 1,67 menit pukul 13.15 - 14.15 dan 13.30 - 14.30 WITA pada hari Rabu, frekuensi terendah sebesar $21 \mathrm{kend} / \mathrm{jam}$ dengan headway tertinggi sebesar 2,86 menit pada pukul 16.00 - 17.00 WITA hari Senin. Adapun frekuensi rata-rata kedua arah angkutan umum penumpang rute Sweta - Ampenan didapatkan sebesar 28 kend/ jam dengan headway waktu rata-rata sebesar 2,12 menit.

\section{Waktu dan Kecepatan Tempuh}

Kecepatan tempuh masing - masing angkutan umum penumpang berdasarkan data waktu tempuh (tabel 2 dan 3) disajikan pada tabel 9 dan 10.

Tabel 9. Waktu Tempuh AUP Rute Sweta - Ampenan arah Sweta - Ampenan (Jam)

\begin{tabular}{lcccccccccccc}
\hline & \multicolumn{4}{c}{ Sweta - Ampenan } & & \multicolumn{4}{c}{ Ampenan - Sweta } \\
& Sabtu & $\begin{array}{c}\text { Ming } \\
\mathrm{u}\end{array}$ & Senin & $\begin{array}{c}\text { Selas } \\
\mathrm{a}\end{array}$ & Rabu & Kamis & Sabtu & $\begin{array}{c}\text { Mingg } \\
\mathrm{u}\end{array}$ & $\begin{array}{c}\text { Seni } \\
\mathrm{n}\end{array}$ & $\begin{array}{c}\text { Selas } \\
\mathrm{a}\end{array}$ & $\begin{array}{c}\text { Rabu } \\
\text { Kamis }\end{array}$ \\
\hline $\begin{array}{l}\text { Maksimu } \\
\mathrm{m}\end{array}$ & 1,03 & 1,02 & 1,08 & 1,08 & 0,98 & 1,03 & 1,05 & 1,03 & 1,02 & 1,05 & 1,03 & 1,05 \\
\hline
\end{tabular}




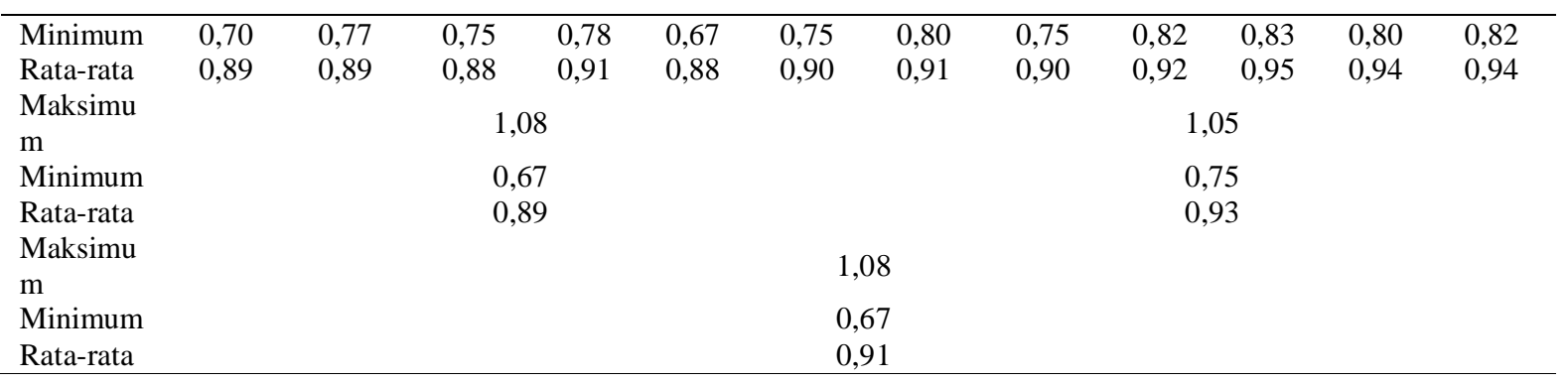

Sumber : Hasil Perhitungan

Tabel 10. Kecepatan Tempuh AUP Rute Sweta - Ampenan arah Ampenan - Sweta (Km/Jam)

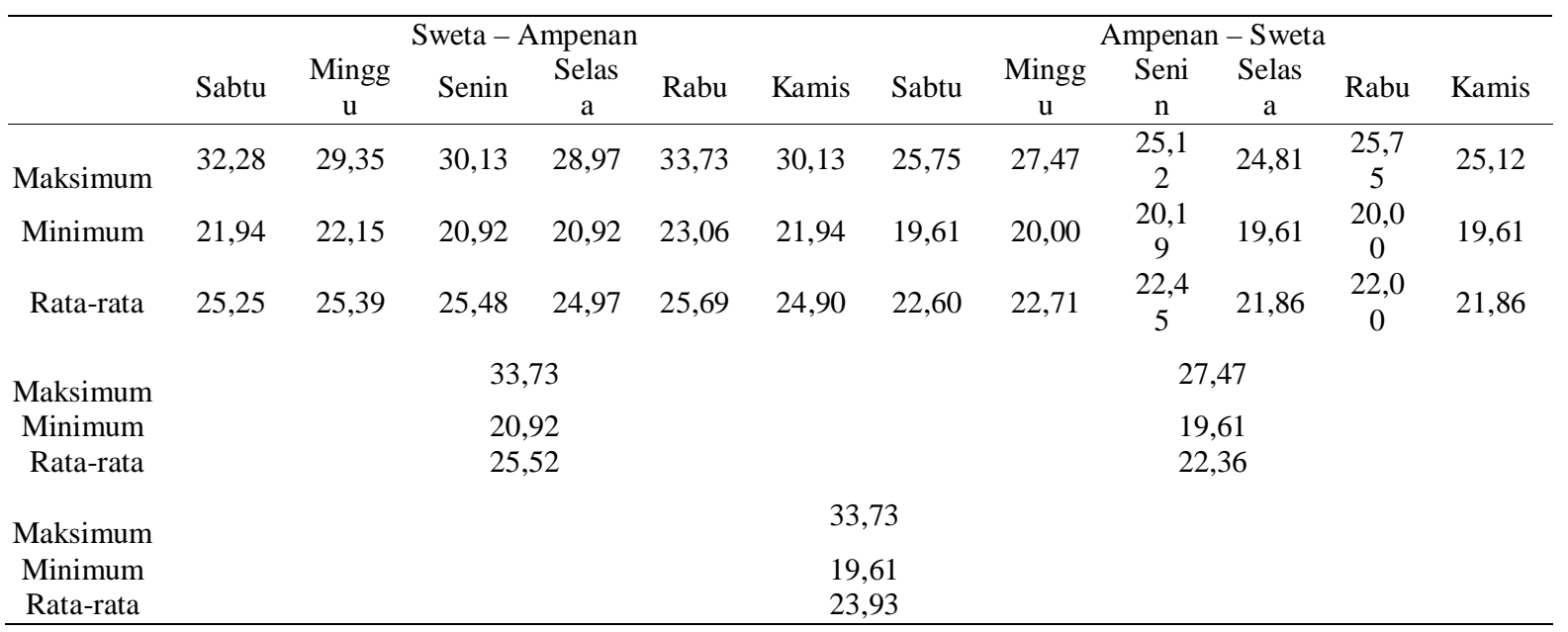

Sumber : Hasil Perhitungan

Angkutan umum penumpang arah Sweta Ampenan, waktu tempuh maksimum sebesar 65 Menit (1,08 jam) dengan kecepatan tempuh minimum sebesar $20,92 \mathrm{~km} / \mathrm{jam}$ terjadi pada keberangkatan pukul 10.00 dan 17.00 WITA hari Senin, Selasa. Sedangkan waktu tempuh minimum sebesar 40 menit $(0,67$ jam $)$ dengan kecepatan tempuh maksimum sebesar $33,73 \mathrm{~km} / \mathrm{jam}$ terjadi pada keberangkatan pukul 13.00 WITA hari Rabu. Untuk arah Ampenan - Sweta, waktu tempuh maksimum sebesar 63 menit $(1,05$ jam $)$ dengan kecepatan tempuh minimum sebesar 19,61 km/jam terjadi pada keberangkatan pukul 16.00 dan 18.00 WITA hari Sabtu, Selasa dan Kamis. Sedangkan waktu tempuh minimum sebesar 45 menit $(0,75$ jam $)$ dengan kecepatan tempuh maksimum sebesar 27,47 km/jam terjadi pada keberangkatan pukul 06.30 WITA hari Minggu. Adapun waktu tempuh rata-rata kedua arah sebesar 54 menit $(0,91$ jam) dan kecepatan tempuh rata-rata kedua arah sebesar $23,93 \mathrm{~km} / \mathrm{jam}$.

\section{Pembahasan}

Hasil evaluasi kinerja angkutan umum penumpang rute Sweta - Ampenan arah Sweta -
Ampenan diketahui, load factor rata - rata sebesar $57,29 \%$, frekuensi rata - rata sebesar $28 \mathrm{kend} / \mathrm{jam}$, headway rata - rata sebesar 2,14 menit dan kecepatan tempuh rata - rata sebesar $25,52 \mathrm{~km} /$ jam. Untuk arah Ampenan Sweta diketahui nilai load factor rata - rata sebesar $44,18 \%$, frekuensi rata - rata sebesar $28 \mathrm{kend} / \mathrm{jam}$, headway rata - rata sebesar 2,11 menit dan kecepatan tempuh rata rata sebesar 22,36 km/jam. Sedangkan untuk kedua arah diketahui nilai load factor rata - rata 50,74 $\%$, frekuensi rata - rata $28 \mathrm{kend} / \mathrm{jam}$, headway rata - rata 2,12 menit, dan kecepatan tempuh rata - rata $23,93 \mathrm{~km} / \mathrm{jam}$.

Tingkat keterisian angkutan umum penumpang berdasarkan data naik turun penumpang (tabel 4), diketahui dalam satu kali perjalanan jumlah penumpang maksimum 8 penumpang dan minimum 2 penumpang. Dengan mengestimasi jumlah penumpang yang diangkut setiap kendaraan dalam satu hari berdasarkan data jumlah penumpang (tabel 2 dan tabel3) diketahui rata-rata penumpang sebesar $7 \mathrm{pnp} /$ kend dengan trip rata - rata 4 trip/hari-kend, maka dapat diestimasi jumlah penumpang (volume) angkutan umum penumpang setiap harinya sebesar 4620 
pnp/hari. Berdasarkan jumlah armada angkutan umum penumpang Sweta - Ampenan 165 unit dengan kapasitas 12 pnp/kend, jumlah trip rata rata 4 trip/hari-kend, maka kapasitas angkutan umum penumpang 7920 penumpang/hari. Dengan demikian angkutan umum penumpang rute Sweta - Ampenan memiliki armada (kapasitas) yang lebih besar daripada demand / permintaan ( $42 \%$ dari Kapasitas).

\section{Tinjauan Produktivitas AUP}

Berdasarkan waktu operasional mulai pukul 06.00 - 18.00 WITA dan data frekuensi angkutan umum Sweta - Ampenan (tabel 5) diperkirakan jumlah trip angkutan maksimum 725 trip/hari (Rabu) dan minimum 691 trip/hari (Minggu dan Sabtu), jumlah trip rata - rata 4 trip/hari-kend.

Berdasarkan uraian diatas diartikan bahwa angkutan umum penumpang rute Sweta - Ampenan memiliki armada (kapasitas) yang lebih besar daripada demand. Berdasarkan jumlah penumpang (kondisi eksisting) 4620 pnp/hari, tingkat keterisian minimum $70 \%$ dari kapasitas ( 8 pnp/trip ) dan jumlah trip proporsional 8 trip/hari-kend (asumsi 4 PP dan jam operasional sekitar 12 jam) maka dapat diestimasi kebutuhan armada angkutan umum penumpang rute Sweta - Ampenan sebesar 72 unit.

\section{KESIMPULAN DAN SARAN}

Kinerja Angkutan Umum Penumpang Kota Mataram rute Sweta - Ampenan : load factor rata - rata angkutan umum penumpang Sweta Ampenan 50,74 \%, frekuensi rata - rata 28 kend/ jam, headway rata - rata 2,12 menit, dan kecepatan tempuh rata - rata $23,93 \mathrm{~km} / \mathrm{jam}$.

\section{DAFTAR PUSTAKA}

Abubakar, Iskandar Ir. 1995. Menuju lalu Lintas dan Angkutan Jalan Yang Tertib, Direktorat Jenderal Perhubungan Darat.Jakarta.

Akbardin, Juan. Evaluasi Kinerja Angkutan Umum Penumpang Wilayah Pesisir Pantai Morodemak. Jurnal Teknik Universitas Sultan Fatah. Nomor 1 September 2005. Jurusan Teknik Sipil, Fakultas Tekink, Universitas Sultan Fatah Demak.
Asikin, Muslich Zainal. 2001. Sistem Manajemen Transportasi Kota. Yogyakarta : Penerbit UGM.

Direktorat Jendral Perhubungan Darat. 1996. Pedoman Teknis Penyelenggaraan Angkutan Penumpang Umum Di Wilayah Perkotaan Dalam Trayek Tetap Dan Teratur.

Keputusan Jenderal Perhubungan Darat SK.687/ AJ.206/DRJD/2002. Tentang Pedoman Teknis Penyelenggaraan Angkutan Penumpang Umum Di Wilayah Perkotaan Dalam Trayek Tetap Dan Teratur. Jakarta: Departemen Perhubungan.

Peraturan Menteri Perhubungan Republik Indonesia Nomor Pm.10 Tahun 2012 Tentang Standar Pelayanan Minimal Angkutan Massal Berbasis Jalan.

Suprihati, Eni. Evaluasi Kinerja Operasi Angkutan Umum Perdesaan Kabupaten Bantul Daerah Istimewa Yogyakarta. Makalah Simposium IX FSTPT, Universitas Brawijaya. $17-18$ November 2006. Jurusan Teknik Sipil, Fakultas Teknik, Universitas Gadjah Mada Yogyakarta. Susilowati DKK. Kajian Kinerja Angkutan Dengan Metode Quality Function Deployment (QFD) Pada Kawasan Industri Marmer Di Kabupaten Tulungagung. Jurnal Rekayasa Sipil/ Volume5, No.3 - 2011 ISSN 1979 - 5658. Jurusan Teknik Sipil, Fakultas Teknik, Universitas Brawijaya Malang.

Warpani, Suwardjoko. 2002. Merencanakan

Sistem Perangkutan. Bandung: Penerbit ITB. 